\title{
The oligarchical tradition of the judiciary in Brazil
}

\begin{abstract}
A permanent feature of Brazilian society is its structural duality; i.e, behind the official world has always had a very different reality in fact, dominated by oligarchic power. The body of judges between us, always integrated the frames of dominant social groups, fully sharing their mentality, that is, their strengths and weaknesses, including the endemic corruption addiction. In the colonial period, the administration of justice was up to the powerful interior, which held the posts colonels or captains mores militia. Unia is thus the military with economic power, which made the administration of justice a real travesty. This situation remained unchanged throughout the imperial period. During the call "Old Republic" supported the federalist ideas, the actual dominance of local potentates on the rulers intensified enormously. During the Vargas period, with the short interregnum of the 1934 Constitution, all constitutional guarantees of the judiciary were suspended, turning into effect only with the Constitution of 1946 . The State 1964 coup established a corporatemilitary regime, which suppressed all the fundamental rights and guarantees, including the judiciary; although the latter have been nominally restored in 1979 with the enactment of the Organic Law of the National Judiciary. In fact, the rule of law only came into force in our country with the promulgation of the 1988 Constitution. In 2004, Constitutional Amendment 45 created the National Council of Justice, with the function to control all the organs of the judiciary. The Supreme Court, however, dodged the submission to this control. Currently, impose are two major reforms in the judiciary organization: 1) the expansion and deepening of the control of their bodies; 2) the introduction of new instruments of control of these bodies.
\end{abstract}

Keywords: national judiciary, colonization, brazilian society, slaves
Volume 4 Issue 5 - 2019

\author{
Fábio Konder Comparato \\ Emeritus Professor, Faculty of Law, University of São Paulo, \\ Brazil
}

Correspondence: Fábio Konder Comparato, Emeritus Professor, Faculty of Law, University of São Paulo, Brazil, Email fkcomparato@gmail.com

Received: August 24, 2019 | Published: October 30, 2019

\section{Introduction}

The judicial function is essential to any political organization. It was from the institution of the royal courts in the Middle Ages, ensuring peace and justice to the poorest populations, exploited by feudal barons and despised by the ecclesiastical authorities, who was born and could develop in the modern state. ${ }^{1}$ That being so, one can not help wondering:-Who is to be attributed to the state judicial function? Because of that, should the holders of that power exercise it? It is permissible for the judiciary to act without controls? The answer to these fundamental questions can not be made on a purely theoretical level, without a concrete analysis of the social reality in which it operates political organization. This reality is defined essentially by two closely related factors: on the one hand, the actual structure (not only official) of power within the society; on the other hand, the current collective mentality, being understood as such the set of ethical values predominant in the social environment. In the contemporary state, notably in the framework of capitalist civilization, the collective mentality has to be shaped decisively by the holder of supreme power social group, according to their own interests. Let us therefore begin by trying to define, based on these structural elements, the very characteristic of the Brazilian social reality in the five centuries of its historical development, in order to understand, then the performance of the judiciary within this broader social context, and conclude with a proposal to change due to the common good.

${ }^{1}$ Joseph R Strayer. On the Origins of the Modern State. Princeton University Press; 1970. p. 38.

\section{The structural dualism of the brazilian society}

Since the first decades of Portuguese colonization, here organized society had a dual character: behind the official legal world, protocolarmente respected, has always had a very different reality in fact, usually hidden from the external looks, reality this at all in the interests own the holders of effective power. The latter, throughout our historical evolution, they formed a team, made up by the alliance of private economic potentates with large state agents. The components of this political couple, since the colonial enterprise-for the colonization of Brazil, as well emphasized Caio Prado Jr., ${ }^{2}$ We had a distinctly commercial character-sought, first of all, realize their own interests and not the common good of the people. In fact, this business-state wedlock, quite contrary to what the ideology of economic liberalism, is the essence of the capitalist system. ${ }^{3}$ Now, since the beginning of colonization, Brazil was provided with a structure of power and a collective mentality marked by the "capitalist spirit" that Max Weber spoke. Consequently, it never existed, within our dominant groups, a clear awareness of public assets: the state resources, even when coming from taxes, have always been regarded as a kind of active balance of de facto partnership, formed by private entrepreneurs and State agents. Where it took place the fact that corruption only give rise to criminal proceedings when opening small amount. For large corrupt-at least until recently, and outside the Central Administration!always prevailed the old custom of impunity. That is, let him be fat! as illustrated Machado de Assis in famous tale of Old House Relics

${ }^{2}$ Brazil's training Contemporary. first ed. 1942.

${ }^{3}$ Fernand Braudel. La dynamique du capitalisme. Paris: Flammarion; 2008. 68 p. 
Another decisive factor, The consolidation of the power structure and the formation of the Brazilian national character was the cool persistence of slave labor system for almost four centuries. It should be noted that the practice of slavery was not confined to the business sector, mainly the agricultural season, but also covered, broadly, the urban, domestic life and the Catholic Church itself. As pointed out the Viscount of Cairo in a letter to a friend, dated 1781, "is proof of extreme begging not having a slave." Among the various socio-political effects engendered by slavery in Brazil, two are worth mentioning. First, the non-acceptance, the collective mentality and social customs, the principle that "all human beings are born free and equal in dignity and rights", as proclaims the Article One of the Universal Declaration of Human Rights 1948 . social inequality with which we face every day, you seldom offend; it appears instead as something inherent to human nature itself. Politically, the predominant belief that power can only be effectively exercised by the top layer of the population, the evil called elite, and popular sovereignty expressed in the first article of our present Constitution, is ideal mere rhetorical. Here again, as we see, there exists duplication of legal systems, figuring the official as simple facade of the public building, inside which-hidden from outside eyes-life is organized very differently. The second adverse effect of slavery in the organization of Brazilian society is tolerance of abuse of power, public or private, old heritage of criminal immunity that always enjoyed the great slaveholders. The excesses or abuses of power are considered normal events. As good examples of institutionalized anomaly, just remember the lack of punishment for state agents, responsible for countless atrocities systematically committed during the Vargas dictatorship and the business-military regime in 1964. In both these paradigmatic cases, in order to "turn the page "at the end of the authoritarian regime, the oligarchs laid hands of the amnesty institute, with the judiciary pleasure.

\section{Judiciary's position in the context of the brazilian social reality}

OBody judges between us, always integrated in general the frames of dominant social groups, fully sharing their mentality, that is, your preferences evaluative, beliefs and prejudices; which contributed decisively to consolidate functional duplicity of our legal systems in this field. That is, our judges always interpreted the official law in the light of the potentates of private interests, in collusion with state officials, as it becomes exposed.

\section{Brazil colony}

Throughout the colonial period, as the cities within the territory were few in number and very distant from each other, the judicial authorities were never able to exercise effectively its functions in the vast areas where extended their jurisdiction. The natural consequence was that the administration of justice fit, inevitably, the powerful of the hinterland, which held the posts colonels or captains mores militia. Unia is thus the military with economic power, which made the administration of justice a real travesty. Counselors King in Lisbon sought to correct this distortion at the end of the century XVII Editing several measures, including the limitation of the exercise of the military function of time of Captain-General and the appointment of ordinary judges, in principle not subject to the power of the big landowners. Of course, such measures did not produce any effect, as if only because it was impossible to find in the backcountry literate people in sufficient numbers to perform the duties of magistrates. Brought this matter to the attention of the Crown of counselors, they replied that they hardly mattered were illiterate judges, as long as his immediate assistants could read and write. ${ }^{4}$ In fact, it was the strong ${ }^{4}$ About this entire subject, cf. CR Boxer. The Golden Age of Brazil-1695/1750. bond of kinship or crony of local magistrates with the chief quality families, which led to the creation of outside judges. As clarified in 1715 the Angeja Marquis, Viceroy of Brazil, with this new kind of magistrates sought to prevent local judges "allow the guilty to continue their crimes, because of kinship or deference." ${ }^{5}$ This, not to mention the usual fact that several judges become farmers or traders, despite the legal incompatibility of performance of official duties with the exercise of private economic activity, either on their own behalf or through relatives or friends. As judicial review bodies, but also exercising administrative functions, we had initially grantees then the captains mores and captains-general, and finally the GovernorGeneral then called Viceroy. Then were created with appellate jurisdiction and internal affairs of the lower court judges, ombudsmen of the district, and above these general ombudsmen, all appointed by the King. In the centuries XVII and XVIII, Were founded respectively in Bahia and Rio de Janeiro, two Courts of Appeal, with revisional jurisdiction ultimately these courts whose president was born the Governor General, then Viceroy. ${ }^{6}$

None of these higher judicial bodies, however, was able to exert the necessary control of the acts of administrative authorities. Was it usual that the Governors, as the presidents of the Courts of Appeal, sought to reconcile the good graces of the judges, adding to ordained these, extraordinary bonuses called tuition. ${ }^{7}$ And as to the examination which must be exercised by the Overseas Council on all the officials here in office, she always left much to be desired as to the century XVIII there was only one official per year sea voyage between Lisbon and Brazil. It should be remembered, moreover, that the first Ombudsman General to exercise their functions in Brazil, Judge Pero Borges, arrived here with Thomas de Souza in 1549, had a functional after a short clean. In 1547, he was ordered to return to the Royal Treasury the money diverted from the works of construction of an aqueduct, whose supervision had been charged in his capacity as Magistrate of Justice in Elvas, Alentejo. The same sentence suspended him for three years from the exercise of public office. However, on December 17, 1548 the King appointed the Ombudsman-General in Brazil, that is, the greater judicial authority under the Governor-General. That is to say: to the exercise of public office in this land previous criminal convictions nothing counted. ${ }^{8}$ For we realize the majority of cases of malfeasance magistrates in the colonial period, just read some offices of Mayors of Bahia ratio of Courts and the Rio de Janeiro-century XVIII. On January 22.1725, for example, Vasco Fernandes Cesar de Menezes wrote from Bahia to the King of Portugal as follows: "Lord-the Council give consideration to Overseas V evil Majesty to proceed Ombudsmen of Ceará, Paraíba, Alagoas, Sergipe del Rei, Rio de Janeiro and São Paulo, and the disorders and excesses that are seen all these people so dismayed and oppressed, who are rightly worthy of the grandeur and majesty of V. pity them not dilate the remedy for that with the expansion it does not ruin the last padeçam or cliff that continually causes the cruelty and tyranny of these bachelors, no It is the case of this government and much less of this relationship."

\section{University of California Press; 1962. p. 209,306.}

${ }^{5}$ Stuart B Schwartz. Sovereignty and Society in Colonial Brazil-The High Court of Bahia and its Judges, 1609-1751. University of California Press; 1973. p. $257 / 258,275$.

${ }^{6}$ The Bahia Court of Appeal was opened in 1609 and ran until 1751, the year it was created the Court of Appeals of Rio de Janeiro.

${ }^{7}$ Stuart B Schwartz, op. cit., p. 272.

${ }^{8}$ Eduardo Bueno. Dirty sheet, in the history of Brazil to Occupied, organization Luciano Figueiredo, House of the Word. 2013. p. 254/255.

${ }^{9}$ Quoted by Braz do Amaral, notes and comments to the letters of Luis dos Santos Vilhena, published under the title The Bahia in Century XVIII, vol. II, Publisher Itapuã - Bahia, 1969, pp. 358/359. 
In turn, on June 21, 1768 the Marquis of Lavradio, as Governor and Captain-General of the Captaincy of Bahia de Todos os Santos, Sent an official letter to the Viceroy Conde de Azambuja in Rio de Janeiro, in which, among other facts reports: "The Relation of Body found it in the state that Your Excellency. know the great freedom that they had taken to each other the public interest, they used to take in private business, where they were being judges finally the lack of seriousness with which they were in such a respectful place, everything has me bound not to miss a single day to go preside over the relationship, where I have been several times necessary to show them or tell them the way we should conduct themselves, and the resolution that I am the not fix differently. I am happy that already today there are fewer disputes in that place, not hinder each the votes of others, and seek to promote their proteges more modestly, at least with such rebuço, it is necessary very carefully to discover their particular godchildren ; however, it is certain that still there. ${ }^{10}$

Likewise, in letter sent in 1767 to the Secretary of State Francisco Xavier de Mendonca Furtado, brother of the Marquis of Pombal, the Viceroy of Brazil, Conde da Cunha, and referred to the Court of Appeals of Rio de Janeiro: "The ministers of this relationship, which should contribute to the good harmony of the same court and a good collection of the Royal Treasury, joined the Chancellor João Alberto Castelo Branco, to protect unworthy men, and other debtors of serious sums to the Royal Treasury; these procedures were so excessive that even in the same ratio and beyond made some oversights to the Crown prosecutor." 11 No surprise, therefore, if from an early age among usIn most cases, the judicial service existed not to do justice, but to extort money. In the famous Sermon of St. Anthony Preaching to the Fishes, ${ }^{12}$ Father Vieira denounces the fact in burning words: "You see such a man walking hounded by lawsuits or accused of crimes, and look how many the are eating. Eat it the Bailiff, eat it the Jailer, eat it the Registrar, eat it the Solicitor, eat it Lawyer, eat it the Inquisitor, eat it the Witness, eat it the Judging and still it is not sentenced and is already eaten. Are worse men than crows. The sad it was to be hanged, do not eat the crows until after run and dead; and walking in judgment is not yet executed or sentenced, and is already eaten."

\section{Brazil monarchical}

The permanent duplicity of legal systems-an officer, rarely applied, and other unofficial but always effective-was accentuated after the country's independence. As he wrote Sérgio Buarque de Holanda, “can hardly understand the dominant features of imperial policy without taking into account the presence of a constitution 'unwritten' which, with the complicity of both parties, overlaps in general the letter of 24 and same time will undermine it." 13 The political revolt that led to the independence of the countrymade under the aegis of a small group intellectuals, fascinated by the libertarian and egalitarian ideals of the French Revolution, soon after consolidated in monarchical form, these ideals that inspired the writing of our first Policy Letter. For local economic potentates, however, what mattered above all, was the access to the main administrative and political positions monopolized

${ }^{10}$ Marquis Lavradio. Bahia Letters 1768-1769. Ministry of Justice, National Archives; 1972. 20 p.

${ }^{11}$ Apud Arno Wehling, Maria José Wehling. Law and Justice in Colonial Brazil-The Court of Appeals of Rio de Janeiro (1751-1808). Refresh (Rio de Janeiro, Sao Paulo and Recife); 2004. 310 p.

${ }^{12}$ Preached in New York City in 1654.

${ }^{13}$ General History of the Brazilian Civilization II-The Monarchist Brazil, 5 From Empire to Republic. São Paulo (European Broadcasting's Handbook); 1972. $21 \mathrm{p}$. by overseas men. The 1824 Constitution establishedSolemnly, "the Division of Political Powers and harmony" as "the conservative principle Citizens' Rights and the surest way to make effective the guarantees that the Constitution provides" (art. 9). According to this principle, the judiciary has become one of the four political powers (art. 10). In real life, however, this proclaimed independence of the judiciary in relation to other powers has always been illusory. The magistrates' body remained closely linked to the families of wealthy landowners at local level, and subordinate to the central executive power at court.

In 1827, reproducing existing model in Portugal, the office of justice of the peace was created to be filled by people without specific training and unpaid, elected by the citizens of each parish. The Criminal Procedure Code of 1832, promulgated under the influence of liberal ideas, innovation has confirmed and extended the jurisdiction of the magistrates. In proceedings-crimes, it was up to them to make the corpus delicti, arrest and interrogate suspects, and denounce them before the court of law. In civil cases, should they seek preliminary conciliation between the parties with the power to prosecute claims involving small amounts. Moreover, even they acted magistrates in electoral matters, determining in each election who would have the right to vote. Finally, tournaments still such magistrates various police functions, such as performing the postures of the City Councils on urban order and discipline, resolve disputes between district residents about paths, pastures and damage to another's property, destroy quilombos and command the armed forces which threaten to undo gatherings established order. Excuse to say that such an institution, despite its democratic appearance, has become in reality a key instrument in the exercise of local power by planters and large farmers; which, incidentally, never stolen, in many cases, to make elect themselves as justices of the peace.

On the other hand, in apparent contrast to this hegemony of the hinterland of the powerful, the body of magistrates, except for justices of the peace, remained-especially since the "return policy" of conservatives, established in 1841 with the reform of the Code Criminal proceedings-submitted to the central political power. now it was for the Emperor himself directly name the orphans of judges, municipal judges (with various functions of the justices of the peace), the judges (with broader territorial jurisdiction) and prosecutors. Before long, the submission process of the judiciary to the executive widened. So much so that in Circular of February 7, 1856 to the Presidents of the provinces, the Emperor determined that "racing to the judiciary to apply the occurring cases of criminal laws, civil, commercial and related processes, cease the abuse make many judicial authorities, failing to decide the occurring cases and subjecting them to doubt the decision of the imperial government, why wait, although late is, sobrestando and delaying the administration of justice, that fits in your authority, thus depriving the Superior Courts to decide on appeal and competently doubts that occur in the assessment of facts and law enforcement." 14 Obviously, however, on the occasion of appointments of local magistrates, the political leaders of the Court or the provinces always came to compose with the large rural landowners, as if only because the political elections were decided by them. Here again, therefore, the official legal system did not exist for real, serving the public facade building only. Duplicity even more scandalous occurred throughout the Empire in the matter of slavery. The Constitution of 1824 declared "already abolished flogging,

${ }^{14}$ Apud Joaquim Nabuco. A Statesman of the Empire, Rio de Janeiro (Editora Nova Aguilar). 1975. 233 p. 
torture, hot iron branding and all other cruel" (art. 179, XIX). In 1830 , however, it was promulgated the Criminal Code, which provided for the imposition of sentences of galleys. As provided in its art. 44, it "will subject the defendants to walk with Calceta foot and iron chain, together or separately, and to employ up in public works in the province, which has been committed the offense, to the Government." Excuse to say that this kind of penalty, taken by the legislator not cruel 1830 , applied only to slaves in fact.

And there was more. Despite the express constitutional prohibition, the captives were, until the eve of Abolition, more precisely to the Act of October 16, 1886, marked with red-hot iron, and regularly subject to the penalty of flogging. The same Criminal Code, in its article. 60 , fixed to the slaves maximum fifty (50) stripes per day. But the legal provision has never been respected. It was common for the poor devil suffer up to two hundred lashes in one day. The law referred to was only voted on in the House because, just before two four slaves condemned to 300 lashes by a South Paraíba jury trial died. All this, not to mention the mutilating punishments, like all broken teeth, cut off fingers or pierced breasts. Why, even the abolition, the judiciary never bothered to prevent the application of this unwritten law of slavery, when not least because several judges were owners of farms with good number of slaves. ${ }^{15}$ The best example of this deliberate blindness of the judiciary about the abuses of the slave system was the permanence of the slave trade for many years, in blatant illegality situation.

A decree of January 26, 1818, downloaded by King still Portuguese in Brazil, in compliance with the treaty with England, determined to ban the infamous trade under penalty of loss of slaves, which "will be released immediately." Become the independent country, it has established itself with England new Convention in 1826, in which the traffic to be done after three years from the exchange of ratifications would be equated to piracy. During the regency, under pressure from the British, the ban was reiterated with the enactment of the Law of 7 November 1831. On the content of this legal diploma, were declared free "all slaves who enter the territory or ports of Brazil, coming from out". They would be re-exported "to any part of Africa," and "importers" subject to criminal proceedings; it being understood by "importing" As if simply it was a "law for show," according to the consecrated expression, none of the pens in it sanctioned was never applied in court. It is estimated to have been smuggled here as slaves, since the enactment of that statute until 1850-when entered into force the Eusébio de Queiroz Law, which reiterated the prohibition of the slave trade-no less than 750000 Africans.

Even after the enactment of that law, however, the criminal liability of slave traders and their henchmen no longer fully effective, since jurisdiction over such crimes was the jury, whose members are subjected, obviously the pressure of local potentates. ${ }^{16}$ As pointed Saint-Hilaire, "the fear of revenge, very easy on the inside, where the police are almost powerless, helps to make the most indulgent judges; they are so taken for the good old habit of giving in to all requests (efforts)." He added that until 1847 the very legislation encouraged

${ }^{15} \mathrm{See}$, in this regard the Memoirs of a Magistrate of the Empire, Councilor Albino José Barbosa de Oliveira (Companhia Editora Nacional, the Brazilian Collection Vol. 231, 1943, pp. 246 ff.), Which was judge in two courts the relationship and became, in later life, a counselor of the Supreme Court

${ }^{16}$ This is why the old Nabucco, speaking in the House, proposed to be deleted competence of the jury to judge such crimes. See Joaquim Nabuco, My Education, Publisher 34, 2012. p. 171/172. "excessive softness" of the jurors. ${ }^{17}$ No wonder, therefore, if the effect of the absence of effective official controls on the performance of the judiciary, his honesty during the Empire has left much to be desired. The intellectual mentors of the Constitution of March 24, 1824, no doubt concerned about the long tradition of venality of the judiciary during the colonial period, decided to include two arrangements in order to eradicate it, but to reduce it to the maximum: Art 156-. All Di JudgesReito and Bailiffs are responsible for abuses of power and transgressions they commit in the exercise of their jobs; this responsibility will be effective for regulating Law.

Art 157-. For bribery, bribery, embezzlement and graft, will be against them popular action that may be brought within a year and a day by the complainant himself, or any of the people, kept the order of the process obeyed the law. It is not known whether these constitutional provisions have been met. What is known, however, it is that some illustrious foreign travelers-even the Emperor Pedro II-made it to put into focus the widespread corruption of the judiciary, which raged during the monarchic period. On account of his trip by the provinces of Rio de Janeiro and Minas Gerais, made in the second decade of the century XIX, Auguste de Saint-Hilaire says that "in a country where a long slavery did, so to speak, a kind of corruption of habit, magistrates, free from any kind of surveillance, can with impunity give in to temptation." ${ }^{18}$ At the same time, the merchant John Luccock, who came here after the opening of the ports, commenting on the custom of the acquisition by neighbors, by auction, land seized for nonpayment of taxes, notes: "In this transaction, are observed strictly the legal formalities and has the illusion that the property was awarded to the highest bidder of the auction; but in reality, favoritism prevails over justice and the law, since there is no one quite dared to raise your bid for a person of wealth and influence. "[...]" In fact, it seems that in every rule Brazil to Justice is purchased. This sentiment is found for such ingrained way of customs and general way of thinking, that no illegal considers [the tort]; On the other hand, to protest against the practice of maximum similar seem not only ridiculous, as would only shoot the complainant in complete ruin." ${ }^{19}$ Moreover, as pointed Charles Darwin in his diary of the voyage of the Beagle, ${ }^{20}$ in date of July 3, 1832, when he did stay in Brazil, the dishonesty of Justice was only part of the widespread corruption in the public service: "No matter the size of the charges that may exist against a man of means, it is certain that before long he will be free. Everyone here can be bribed. A man can become a sailor or doctor, or take any other profession, if you can afford enough. It was asserted seriously by Brazilians that the only fault they found in English law was to be able to realize that the rich and respectable people had any advantage over the wretched and the poor." Reportedly, even the highest court of the Empire remained free of corruption. Instatement to Sinimbu Viscount, D. Pedro II blurted: "The first need of the judiciary is effective accountability; and while some judges are not to jail, for example, certain well-known perpetrators of the Supreme Court, if this can not end."21

\footnotetext{
${ }^{17}$ Arthus Bertrand, Libraire-Éditeur. Voyage dans les Provinces of Saint-Paul et de Sainte-Catherine, take first. Paris; 1851. 138 p.

${ }^{18}$ Work published by Editora Itatiaia Limited, in collaboration with the publisher of the University of São Paulo, 1975, p. 157.

${ }^{19}$ Notes on Rio de Janeiro and Southern Parts of Brazil. Publisher of the University of São Paulo, Library Itatiaia Editora Ltda; 1975. 321 p.

${ }^{20}$ The Daily Beagle. Editora UFPR; 2006. 100 p.

${ }^{21}$ Apud José Murilo de Carvalho, Pedro II-To be or not to be, Companhia das Letras. 2007. $83 \mathrm{p}$.
} 


\section{The Republican period}

The Constitution of 1891, to provide for the Judiciary, established explicitly, but only to federal judges, the tenure security, determining even "their salaries shall be determined by law and can not be reduced" (art. 57, Heading and §1). Such a rule left to assume that these constitutional guarantees are not necessarily applicable to the state judiciary; which was fortunately away. During the military governments of Deodoro and Floriano, there was great political pressure to undergo the trials of the new Supreme Court the power to end control of the Senate. The Charter established policy, the image of the US Constitution, the powers of the Senate to judge the Justices of the Supreme in case of impeachment, it was argued that even outside this hypothesis, it would be to that political body review the decisions of the highest Court of Justice. This absurd opinion received long and deep refutation by Rui Barbosa, in his inaugural speech partner in place of the Lawyers Institute at its meeting on May 11, 1911.22 She was, after all, abandoned. Register, however, the disheartening conclusion João Mangabeira acting on the Supreme Court, since its establishment until the beginning of the New State Vargas in 1937: ${ }^{23}$

"The body that the Constitution had created for his supreme guard, is intended to contain at the same time, the excesses of Congress and the violence of the government, left helpless in the days of risk or of terror, when, exactly, needier she was loyalty, fidelity and courage of its defenders." Register even during the Old Republic, supported the federalist ideas, the actual dominance of local potentates (The famous "colonels") on the rulers intensified enormously. The 1934 Constitution, in force only for three years, he added for the benefit of judges, as well as tenure and irreducibility of salaries, also the guarantee of tenure, without making distinctions between judges or federal and state courts (art. 64). He decided, however, that "judges, although in availability, can not exercise any other public function, except the teaching and the cases provided for in the Constitution"; adding that "the violation of this precept matter the loss of judicial office and all the corresponding benefits" (art. 65). The 1946 Constitution established for judges in general, in addition to the three above-mentioned guarantees, the determination that "retirement is compulsory at seventy years of age or proven disability, and optional after thirty years of public service, counted in the form of law "(art. 95).

Established the corporate-military regime of exception with the 1964 coup, remained proforma the validity of the constitutional order, with the suppression of fact of individual liberties and guarantees, as well as social rights. On December 13, 1968, the socalled Institutional Act No. 5 emasculated the judiciary, the decree the official suspension of constitutional or legal guarantees of tenure, tenure and stability (art. 6), in addition to formalize the suspension of habeas corpus "in cases political crimes against national security, economic and social order and people's economy "(art. 10). So much for Civil Justice, as the military justice system, throughout the duration of the authoritarian regime, shamelessly collaborated in the repression of political opponents. ${ }^{24}$ Upon termination of the regimen ${ }^{22}$ Rui Barbosa. Writings and Speeches Treasures Volume. Rio de Janeiro: Editora Aguilar Company; 1966. p. 548.

${ }^{23}$ Rui. The Statesman of the Republic, Brazilian Collection Documents No. 40 Bookstore José Olympio Editora. 1943.78 p.

${ }^{24}$ See in this regard the study of Anthony W. Pereira, Political (In) Justice - Authoritarianism and the Rule of Law in Brazil, Chile, and Argentina, University of Pittsburgh Press, 2005; whose Brazilian edition was published under the dictatorship and repression - Authoritarianism and the rule of law in authoritarian, was enacted in 1988 the Federal Constitution in force, which regulated the judiciary with much greater amplitude than all previous ones. In fact, already in the final phase of the authoritarian regime, exactly on March 14, 1979, Complementary Law No. 35 was issued, establishing the Organic Law of the National Judiciary. Among other provisions, this law created the National Council of Magistrates. In 1998, however, in simple order for one of his Ministers, the Supreme Court declared it extinct, because the occurrence to that Complementary Law of the Constitution of 1988, which had nothing about the mentioned Council. He was, after all, risen, now under the name of National Council of Justice, Constitutional Amendment No. 45 of December 8, 2004.

The creation of the judiciary watchdog came undoubtedly meet the need-long felt since the colonial period, as recalled above-to establish a broader liability regime and need the judges. The reaction of these the creation of the new body, however, was immediately very negative. Even before their official publication, Amendment No. 45 has been the subject of a direct action of unconstitutionality (ADI 3367), proposed by the Association of Brazilian Magistrates. The Supreme Court, while unanimously away the procedural defect of unconstitutionality, as decided by majority-only dismiss the action in its entirety. It should be noted, finally, as a significant event of an early change in the conservative mentality of our magistrates, the foundation on May 13, 1991 the Association Judges for Democracy. She has the statutory objectives the defense of democratic rule of law, founded on the dignity of the human person, the internal democratization of the judiciary as well as the enhancement of judicial functions as a true public service, ie service to the people.

\section{The necessary reforms in the judiciary organization}

For all the above, it is clear that some reforms are necessary in order to eliminate old malfunctioning of institutions of Justice in our country. Here it is, in my opinion, seem more important.

\section{Broaden and deepen the judiciary control instruments}

Undoubtedly, the creation of the National Council of Justice represented a step forward in improving the judiciary's control system. The current structure of the body, however, suffers from serious defects. First, it is not properly structured to exercise their duties throughout the national territory. The Council should rely on ancillary units in each state of the federation. In addition, the body is mostly made up of members of the judiciary itself subject to control. For this reason, it seems, the Council has avoided systematically, even in cases of serious crimes, apply to magistrates, especially the members of the superior courts, the penalty of dismissal provided for in art. 42, itemSAWOf the Organic Law of the National Judiciary. It should be noted also that the members of the Supreme Court are not subject to the control of the National Judicial Council. In fact, by the way, the Ministers of our highest Court of Justice are not subject to any liability in the exercise of its functions, whether judicial or administrative. This status has been transposed totally irresponsible of the US Constitution, which, in this particular, aroused severe criticism of Thomas Jefferson. "When you want to establish three departments, coordinated and independent, so that each can control others and be they control (" that They Might check and balance one another "), the

Brazil, Chile and Argentina, Paz e Terra, 2010. In this study, it is emphasized that while in Chile and Argentina Power judiciary was clearly away from the repressive system among us the bodies of Military Justice had no difficulty in supporting repression. 
Constitution assigned to one of them the right to prescribe rules for the activities of the other, and did just in favor of that which is not elected by the nation and remains independent of it. ${ }^{25}$

Neither of us, this constitutional remedy inspires any kind of fear within the Supreme Court. This, not to mention the fact that the case proceedings of the entire Republican period not register any case in which the judges of our highest court have been accused of criminal acts and, therefore, constrained to respond to criminal proceedings. It would, however, daring to say that cases like that have raised the ire of Dom Pedro II in relation to the Supreme Court of Justice Empire never occurred in the post-monarchical period? Now it is extremely embarrassing to see that even compliance with the provisions of the Internal Rules of the Supreme Court may be imposed on their Ministers. Take, for example, the standard of art. 337, 2 of this Procedure, relating to the processing of requests for clarification: "Regardless of distribution or preparation, the petition will be addressed to the judgment of the rapporteur that, without further formality, to submit to trial in the first session of the Group or the Plenary, as appropriate. "Well, in the event of national and international concern, namely the accusation of breach of fundamental precept No. 153 on the 1979 amnesty law, the rapporteur of the requests for clarification to the published judgment in May 2010, until the time of writing these linesthat is, for almost five (5) years!-although repeatedly requested by the objector, he submitted the appeal to trial.

Another example of blatant disregard for the rule contained in the Internal Rules of the Supreme Court occurred during the trial of the direct action of unconstitutionality No. 4650, brought by the Federal Council of the Bar Association of Brazil, aiming at the corporate financing of election campaigns. In a plenary session held in April 2014 , after the sixth vote by the merit of the action-that is, when already had reached the decisive majority-the Minister called to vote in sequence asked to examine the records, and until the beginning of the judicial year in 2015 there was also presented to the continuation of the vote. Now the art. 134 of the Internal Rules provides, verbatim: "If any of the Ministers ask to examine the records, should present them to continue voting until the second subsequent ordinary session." Does the Federal Constitution (art. 5, subsection XXV) That "the law does not exclude from review by the Judiciary injury or threat to a right." What is not allowed then the law will be tolerated by chance individually to members of our highest Court of Justice? Apparently, behind the constitutional antojo there muffled another system, assigning each of the Supreme Court Minister the discretion to suspend, indefinitely, the processing of an appeal, or the trial has started on the merits of any issue, according to its suggestion itself.

\section{Institute instrument vertical, internal and external control of the judiciary}

Traditionally, the system of so-called representative democracy such as ours, the state agencies are not required to be accountable directly to the people of antijuridicidade of their acts or omissions. An exception to this rule among us has been the popular action. In the 1824 constitution system, as seen, any citizen, as a procedural substitute of the people, could he tries against right and bailiffs judges, "for bribery, bribery, embezzlement and graft." The Federal Constitution of 1891, however, did not reproduce that provision. From the 1934 Constitution (art. 114, paragraph 38), any citizen has become a legitimate party

${ }^{25}$ Thomas Jefferson Political Writings. Cambridge University Press; 1999. 378 p. to claim in court the annulment or declaration of invalidity of acts detrimental to public property. The current Constitution extends the appropriateness of such action in cases of damage to property that the State participates, as well as "administrative morality, the environment and the historical and cultural heritage" (art. 5, subsection LXXIII). But this action is incabível against acts or omissions of the judiciary. Undoubtedly, it is allowed any citizen to report before the Senate Ministers of the Supreme Court the responsibility of crimes they commit (Law No. 1079 of 1950, art. 41). Such complaint, however, never took place, nor think that if one day was done, the Senators of the Republic had the courage to receive it and process it.

Under these conditions, in order to cover the gaps in the vertical field control of members of the judiciary, it seems highly advisable to set up public ombudsman before the Court of agencies around the country, with no exceptions. Listeners necessarily bachelors in law, would be elected by the people to exercise these functions for a specified period and may be reelected. They would have jurisdiction to open and preside over inquiries where there were suspected violation by the magistrate expressed the duties and prohibitions in the Organic Law of the National Judicial (Articles 35 and 36). If official investigations confirm the suspicion, the ombudsmen would propose, before the National Judicial Council, the application of the sanctions provided for therein. Should the inquiry shows that the practice of crime, Also in the vertical control level, it is essential to leave expressed in the Constitution that the national judiciary has the duty to comply with the decisions of international courts of justice, when the Brazilian government officially accepted them submit.

Remember, by the way, the Case of Gomes Lund et al v. Brazil ("Araguaia Guerrilla"), in which our country was convicted unanimously. The Inter-American Court of Human Rights, prolatora the decision on November 26, 2010, he decided that "the provisions of the Brazilian Amnesty Law that prevent the investigation and punishment of serious human rights violations are incompatible with the American Convention, lack legal effect and can not continue to represent an obstacle to the investigation of the facts of the case, or to the identification and punishment of those responsible, nor can they have equal or similar impact regarding other cases of serious human rights violations under the American Convention that took place in Brazil." Now, several Brazilian judiciary, starting with the Supreme Court, have refused to fulfill this international decision; It is leading a political party to propose, on May 15, 2014, the accusation of breach of fundamental precept No. 320, which received a favorable opinion on great part of the Attorney General's Office. The non-execution of the said sentence was, after all, officially recognized by the very InterAmerican Court of Human Rights in its Resolution of 17 October 2014.

\section{Change at the top of the judicial system}

It should be remembered, in this topic, the Proposed Constitutional Amendment No. 275/2013, are pending before the House of Representatives. Its primary purpose is the transformation of the Supreme Court in a Constitutional Court by modifying their competence and manner of appointment of its ministers. In addition, the PEC in question determines the increase in the number of components of Ministers Superior Court of Justice and extended its jurisdiction. The organization of the Supreme Court, in effect, suffers from serious defects, both in the form of its composition as in relation to the scope of their competence.Are played, then the reasons 
which justify mentioned proposed constitutional amendment. And all our republican constitutions, it was determined, according to the American model, that the appointment of the Justices of the Supreme Court is made by the President with the approval of the Senate.

In the United States, the senatorial control works properly and has already been criticism twelve persons appointed by the Head of State to the Supreme Court. Sometimes, when the Head of State realizes that the person chosen by him will not be approved by the Senate, withdrew the nomination. In Brazil, by contrast, to date only the Senate rejected an appointment to the Supreme Court. The unusual event occurred in the troubled period of the beginning of the Republic, when the arbitrary military interventions enacted by Floriano Peixoto in several states raised the host, by the Supreme Court, the extensive doctrine of habeas corpus, supported by Rui Barbosa. Outraged, Marshal President decided, in retaliation, appoint to fill a vacancy on the highest court of the country's Justice Dr. Barata Ribeiro, who was his personal physician. Literally, there was no violation of the constitutional text as the Charter of 1891 required that citizens appointed to the Supreme Court had "remarkable knowledge and reputation"; which no one could deny the Dr. Barata Ribeiro. It was only by Constitutional Amendment of 1926. But this additive qualification has not changed the practice of appointments to the Supreme Court. Continues today the absolute hegemony of the Head of State in the fulfillment of this constitutional assignment. This does not mean that the nominees are not necessarily up to the job; but the fact is that, with this choice made so-only the Head of State, this easily gives in to his personal feelings in its final decision, and suffer all sorts pressures, due to the multitude of informal applications. With regard to the competence of the Supreme Court, there is another serious deficiency. The Federal Constitution of 1988 ascribed to him, as main objective, "to guard the Constitution" (art. 102). But achieving that higher purpose is simply obliterated by the accumulation of assignments to judge pure processes individual interest or private groups, with no constitutional relevance. In order to correct these serious defects in the functioning of the Supreme Court, the PEC 275/2013 determines be it transformed into a genuine constitutional court, to increase the number of its members and reduced their competence.

The new court would beThus composed of fifteen (15) Ministers ${ }^{26}$ appointed by the President of the National Congress, after approval of their names by an absolute majority of the members of the House of Representatives and the Senate, from panels of three candidates, coming from the judiciary, prosecution and advocacy. Such lists would be prepared, respectively, by the National Council of Justice, the National Council of the Public Ministry and the Federal Council of the Bar Association of Brazil. Transiently, the present Justices of the Supreme Court would compose the Constitutional Court, with the addition of four new members appointed as indicated above. The new naming system would makemuch more difficult than it is today successfully engage any lobby in favor of a given application; and to establish, from the start, a selection of candidates according to a presumed legal knowledge. Under the PEC 275/2013, the powers of

${ }^{26}$ To remember that the Federal Constitution of 1891, creating the Supreme Court ruled that it was composed of "fifteen judges" (art. 56). the Constitutional Court would be limited to the causes that directly say regarding the interpretation and application of the Greater Law, transferring all other jurisdiction of the Superior Court of Justice. According to the proposal in focus, the Supreme Court would have a composition similar to the Constitutional Court, but now count with a minimum of sixty (60) Ministers; or almost twice the set currently in the Constitution. The current Justices of the Superior Court of Justice would be kept, providing to the appointment of future ministers in the form of article. 104 of the Federal Constitution, with the new wording of the proposal.

\section{Conclusion}

In famous passage in The Spirit of the Laws, ${ }^{27}$ Montesquieu, in accepting the teaching of John Locke about the necessary tripartite powers in political society, concludes: "Des trois puissances dont nous avons parlé, celle of juger est en quelque façon nulle." The assertion seems blatantly contradictory as how to recognize the judiciary a state of power, and at the same time deny him all power? In fact, the verbal incongruity is overcome when a distinction is made, that Montesquieu himself did, between estatuinte power (la faculté of statuer) and impediente power (la faculté d'empêcher) ${ }^{28}$ In Rome, for example, the tribunes of the people had no power to make laws or order to perform legal acts; but tribunicia potestas (always feared by the patricians) comprised, among other skills, to veto any act of public office holder, contrary to the interests of the common people. Based on this conceptual distinction, it is clear, first, that the judiciary is not for any estatuinte power to create general standards or organizing public services. But he has in the highest degree the impediente power to fix and repair not only the excesses of other public agencies (and also of individuals endowed with power in society), but in theory the supply unconstitutional omissions of state bodies in the exercise of its functions. Now, for this to succeed fully is essential to establishing an effective control system of judicial bodies, as emphasized above. Here again, it is wise to remember the lesson of Montesquieu: ${ }^{29}$ "It is an eternal experience that every man who has power" -and we must add, every state body with power, even constitutional-"is led to abuse it; he goes to where it meets limits." We'll know one day meet this fundamental requirement for true institution of the rule of law in our country?

\section{Acknowledgments}

Study in honor of professor and magistrate Enrique Ricardo Lewandowski.

\section{Conflicts of interest}

Author declares that there is no conflicts of interest.

\section{Funding}

None.

\author{
${ }^{27}$ Book XI, Chapter 6 . \\ ${ }^{28}$ Ibid. \\ ${ }^{29}$ The Spirit of Laws, Book XI, Chapter IV.
}

